\title{
OS SENTIMENTOS DAS PESSOAS QUE AGUARDAM POR UM ÓRGÃO OU TECIDO NA FILA ÚNICA DE TRANSPLANTE
}

\author{
Feelings of people waiting for an organ or tissue transplant in single queue
}

\author{
Givânya Bezerra de Melo, Anne Karolyne Barros Aguiar, Givanisy Bezerra de Melo, Vívian Marcella dos Santos Silva, \\ Maria Cícera dos Santos de Albuquerque, Mércia Zeviani Brêda
}

\begin{abstract}
RESUMO
Objetivo: identificar os sentimentos das pessoas que aguardam por um órgão ou tecido em lista única de transplante. Método: trata-se de uma pesquisa descritiva de natureza qualitativa, realizada junto a sete pessoas aguardando por transplante. Os dados foram submetidos à análise de conteúdo, na modalidade análise temática ou categorial. Resultados: da caracterização dos sujeitos, $57 \%$ são do sexo feminino, faixa etária entre 22 e 62 anos, média de espera por córnea, 2,1 anos e de rim, 3,8 anos. Foram identificados cinco núcleos de sentido no início da espera: prevaleceram sentimentos negativos como tristeza e incertezas diante do diagnóstico e a necessidade do transplante; as mudanças na vida despertaram sentimentos negativos de inutilidade, passividade e culpa relacionados às mudanças financeiras, lazer, liberdade, perspectiva de vida, bem como sentimentos positivos como esperança e superação pela valorização da família e da vida; no enfrentamento, a família foi o recurso mais acessado pelos sujeitos, emergindo sentimentos positivos de confiança e segurança; a assistência à saúde durante a espera foi tomada por sentimentos positivos para os que aguardam por rim e negativos para os que aguardam córnea, por não obtê-la; na ambivalência, revelaram-se sentimentos positivos que aproximam o desejo pela realização do transplante, e negativos que afastam motivados pela dualidade vida/morte, compaixão ao doador vivo; no apelo à vida foram revelados sentimentos positivos de esperança diante das mensagens de sensibilização para incentivo à doação de órgãos. Conclusão: independente do órgão, a espera pelo transplante é um momento estressante na vida dos sujeitos, desencadeando sentimentos múltiplos que precisam ser valorizados. Os resultados remetem a fomentar discussões na formação do enfermeiro e na prática assistencial sobre a importância da valorização da subjetividade das pessoas que aguardam por um transplante, a necessidade de educação em saúde durante a espera, bem como o aperfeiçoamento do Sistema de Captação de Órgãos e Tecidos.
\end{abstract}

Descritores: Enfermagem; Sentimentos; Transplante de Órgãos; Listas de Espera.

Instituições:

${ }^{1}$ Departamento de Enfermagem da Universidade Federal de Alagoas, Maceió, Alagoas, Brasil

${ }^{2}$ Departamento de Enfermagem da Universidade Estadual de Ciências da Saúde de Alagoas, Maceió, Alagoas, Brasil

\section{Correspondência:}

Givânya Bezerra de Melo

Av. Maceió no 88, Tabuleiro dos Martins, CEP 57061-110 - Maceió/AL

Fone: (82) 8814-4927 / 3353-8301

E-mail: givanya@hotmail.com

\section{INTRODUÇÃO}

A realização de transplantes consiste em um avanço significativo da ciência, do Sistema de Saúde e de toda sociedade brasileira. ${ }^{1}$ Embora haja crescimento na taxa efetiva do número de transplantes, o número de órgãos disponíveis não é capaz de suprir a demanda. Ressalta-se que até dezembro de 2011 haviam 21.409 pessoas ativas na lista de espera para transplante de órgãos sólidos; paradoxalmente, durante o mesmo período, concretizaram-se apenas 6.827 transplantes no País. ${ }^{2}$

A realidade brasileira corrobora o contexto mundial. Países como Hong Kong, Estados Unidos e Espanha também apresentam uma desproporção significativa entre o número de órgãos disponíveis para transplante e a demanda emergente. No âmbito mundial, o rim permanece sendo o órgão com maior número de pessoas em lista de espera, porém, com uma disponibilidade que atende apenas $10 \%$ desse total. ${ }^{3}$ 
No Brasil, existe o sistema de lista única, popularmente conhecido como fila única de transplantes, regulamentado pelo Decreto n. ${ }^{\circ}$ 2.268, de 1997. Consiste em um regime de espera em que os órgãos ou tecidos obtidos de um doador falecido, deverão ser distribuídos aos potencias receptores que se encontram cadastrados na fila, conforme critérios específicos. ${ }^{4}$

Obedecendo a critérios de inclusão específicos para cada tipo de órgão, a equipe de saúde, ao identificar um potencial receptor, deve efetuar seu cadastro na CNCDO (Central de Notificação, Captação e Distribuição de Órgãos e Tecidos) da área de residência do usuário. Mediante inscrição na fila única, a CNCDO deverá fornecer ao usuário um comprovante de inclusão, bem como dispor dos critérios de distribuição do órgão ou tecido dos quais que necessitará. ${ }^{5}$

É importante salientar que podem ser utilizados para transplante os órgãos de dois tipos de doadores: o doador vivo e o doador falecido. No que diz respeito ao doador vivo, esse pode dispor de um de seus órgãos duplos ou parte de órgão, desde que não cause mutilação ou prejuízo à saúde. O doador falecido é classificado em dois tipos: doador com o coração parado, do qual podem ser retirados apenas tecidos, como: válvula cardíaca, osso, pele, cartilagens e córneas, e doador com morte encefálica, mas com o batimento do coração mantido através de aparelhos, do qual poderão ser retirados órgãos, como: coração, fígado, pâncreas, rins e pulmão, além dos tecidos já citados, que podem ser retirados do doador também com o coração parado. ${ }^{6}$

No tocante à doação de órgãos entre vivos, há possibilidade de realização de transplantes entre doadores aparentados e não aparentados, desde que haja compatibilidade. As doações entre vivos não aparentados só podem ser efetivadas em casos especiais, devidamente autorizadas pela Justiça, tendo em vista que, no Brasil, qualquer tipo de comercialização de órgãos e tecidos é crime passível das penalidades determinadas em Lei. ${ }^{7} \mathrm{O}$ centro transplantador é responsável por investigar possíveis doadores junto à família do receptor; o receptor deve ser informado da possibilidade desse tipo de transplante, bem como dos seus riscos e benefícios, cabendo a decisão ao receptor e à sua família. A CNCDO só será responsável pelo procedimento cirúrgico através do atendimento dos critérios técnicos estabelecidos. ${ }^{8}$

Estudos referem que as maiores dificuldades para a doação de órgãos e realização de transplantes são de natureza clínicobiológicas, logístico-administrativas, geográficas e culturais, ${ }^{9}$ o que resulta em prejuízo na qualidade de vida dos pacientes e maior tempo de permanência na fila de espera.

O tempo de espera para receber o transplante pode ultrapassar um ano e atingir até nove anos para fígado, e mais de onze para o rim. Os efeitos negativos dessa realidade refletem-se no aumento da espera e sofrimento psíquico para o paciente na fila e sua família, no aproveitamento de órgãos de qualidade inferior e na consequente duração dos enxertos, necessidade de retransplantes e provável elevação nos índices de mortalidade pós-transplante. ${ }^{10}$

Um estudo transversal realizado em Hong Kong em 2011, no qual foram entrevistadas 442 pessoas em lista de espera de transplante, revelou que $23,6 \%$ das pessoas descreveram o período de espera como infeliz ou muito infeliz, 18,8\% apresentam sensação de morte iminente, $14,9 \%$ referiram isolamento social e $6,8 \%$, ideação suicida. ${ }^{11}$

A experiência da espera em todos os casos e tipos de transplantes é vivida sem muita expectativa, causando sofrimento e incerteza, seguida de sentimentos complexos, imprecisos e contraditórios. ${ }^{1}$ Há o temor de não conseguir um órgão a tempo devido às condições de saúde, como também há um anseio de que esse novo órgão não demore a aparecer, acompanhado pelo medo de não suportar o procedimento cirúrgico, além do temor da rejeição e da morte. ${ }^{1}$

O período de espera possui uma qualidade especial: a vida está suspensa, as condições corporais limitam a vida das pessoas. A pessoa permanece acuada a um raio geográfico muito limitado, pois, caso o hospital o chame, deve chegar ao menor tempo possível, em geral, antes de duas horas, ${ }^{1}$ ficando assim, impossibilitada de passear, visitar amigos ou viajar.

Esse contexto limitante e traumático desestabiliza o indivíduo em todas as esferas da sua vida. A subjetividade do sujeito deve ser o foco central de atuação da equipe multiprofissional em saúde; o apoio emocional em todas as fases do transplante é fundamental para minimizar o sofrimento e a tristeza que se fazem presentes de maneira tão intensa na vida desses sujeitos.

$\mathrm{O}$ enfermeiro encontra-se inserido em todo processo de transplante, desde a avaliação inicial do paciente para ser aceito como receptor, até o período pós-transplante.

Nesse ínterim, o cuidado de enfermagem torna-se fundamental para o paciente. O estabelecimento do vínculo, a comunicação terapêutica, a oferta de informações e a responsabilização pelo sujeito são aspectos que devem nortear a prática desses profissionais, tendo como importante ferramenta para sua eficácia a elaboração do plano de cuidado de enfermagem, que deve incluir, além dos aspectos físicos, a consideração pelos sentimentos e emoções, ou seja, a subjetividade do sujeito, objetivando ajudá-lo a enfrentar os desafios e dar sentido a essa fase de sua vida.

Diante das diversas repercussões causadas na vida do indivíduo que aguarda por um órgão na fila única de transplantes e ainda a pouca produção científica relacionada à vivência subjetiva dessas pessoas durante o processo de espera, buscou-se através deste estudo identificar os sentimentos das pessoas que aguardam por um órgão ou tecido na fila única de transplante.

O objetivo do estudo justifica-se em face dos significados dos sentimentos, visto que estes atuam de modo a descrever o que se sente, e imprimem à mente o que é percebido através do contato do corpo físico com a realidade, configurando uma interpretação daquilo que está sendo vivido. ${ }^{12}$ Vislumbrando sua complexidade e profundez, os sentimentos são considerados por Viscott ${ }^{12}$ como o sexto sentido responsável por organizar, dirigir e resumir os outros cinco. 


\section{MÉTODOS}

Considerando as peculiaridades do estudo, optou-se pela metodologia qualitativa descritiva, pois os sujeitos descreveram fenômenos com alto grau de complexidade interna que só poderiam ser captados através da esfera da subjetividade e da significação. A abordagem qualitativa "[...] aprofunda-se no mundo dos significados das ações e relações humanas, de um lado não perceptível e não captável em equações, médias e estatísticas, ou seja, o significado que as pessoas dão às coisas e à vida." ${ }^{13}$

O estudo foi aprovado pelo Comitê de Ética em Pesquisa da Universidade Federal de Alagoas mediante o parecer $n^{\circ}$ 000687/2011. A coleta de dados deu-se no período de agosto a outubro de 2011.

Participaram do estudo sete pessoas cadastradas na fila de transplante, acompanhadas pela CNCDO de Alagoas. Destas, quatro aguardavam transplante renal e três, de córnea. O número de sujeitos do estudo foi definido a partir da saturação das respostas. Esse método, amostra por saturação, trata da suspensão de inclusão de novos participantes, quando os dados obtidos passam a apresentar na avaliação do pesquisador certa redundância ou repetição, ${ }^{14}$ "não sendo considerado relevante persistir na coleta de dados". ${ }^{14}$

Os sujeitos foram selecionados mediante sorteio realizado na CNCDO, utilizando o banco de dados. Após contato telefônico prévio, foi agendado com as pessoas que aceitaram participar do estudo um encontro para realização da entrevista. Todos foram esclarecidos sobre o estudo e fizeram a assinatura do Termo de Consentimento Livre e Esclarecido. Os cenários foram a residência dos sujeitos, CNCDO de Alagoas, além de dois Centros de Hemodiálise localizados na cidade de Maceió, Alagoas.

A coleta de dados foi realizada através de entrevista, por meio de formulário semiestruturado. As falas dos sujeitos foram gravadas, o que permitiu maior fidedignidade e subsídios para uma análise subsequente mais aprofundada. A linguagem não verbal do sujeito durante a entrevista também foi registrada no instrumento. Os dados foram analisados através do método de análise de conteúdo na modalidade técnica, análise temática ou categorial.

\section{RESULTADOS}

Através da análise dos dados, obteve-se que, quatro (57\%) eram do sexo feminino e três $(43 \%)$ do sexo masculino; a idade variou entre 22 e 62 anos, com média de 36,86 anos. $O$ tempo de espera pelo transplante a partir da data de inscrição na fila até a realização da entrevista variou entre 1,5 e três anos para córnea, com média de 2,1 anos; e de quatro a cinco anos para rim, com média de 3,8 anos. As características dos sujeitos são mostradas na Tabela 1.
Tabela 1 - Perfil dos participantes do estudo - Maceió - 2011

\begin{tabular}{|c|c|c|}
\hline VARIÁVEIS & $\mathbf{N}$ & $\%$ \\
\hline \multicolumn{3}{|l|}{ Sexo } \\
\hline Feminino & 04 & 57 \\
\hline Masculino & 03 & 43 \\
\hline \multicolumn{3}{|l|}{ Faixa etária } \\
\hline Até 35 anos & 05 & 71 \\
\hline Mais de 35 anos & 02 & 29 \\
\hline \multicolumn{3}{|l|}{ Nível de escolaridade } \\
\hline Não alfabetizado & 01 & 14,29 \\
\hline Ensino fundamental & 02 & 28,57 \\
\hline Ensino médio & 02 & 28,57 \\
\hline Ensino superior & 02 & 28,57 \\
\hline \multicolumn{3}{|l|}{ Estado Civil } \\
\hline Casado & 04 & 57,14 \\
\hline União estável & 01 & 14,29 \\
\hline Solteiro & 02 & 28,57 \\
\hline \multicolumn{3}{|l|}{ Atividade profissional } \\
\hline Aposentados & 04 & 57,10 \\
\hline Camareiro & 01 & 14,30 \\
\hline Educador físico & 01 & 14,30 \\
\hline Técnico em enfermagem & 01 & 14,30 \\
\hline \multicolumn{3}{|l|}{ Procedência } \\
\hline Arapiraca & 01 & 14,30 \\
\hline Batalha & 01 & 57,10 \\
\hline Maceió & 04 & 14,30 \\
\hline Messias & 01 & 14,30 \\
\hline \multicolumn{3}{|c|}{ Órgão ou tecido que aguarda } \\
\hline Rim & 04 & 57,14 \\
\hline Córnea & 03 & 42,86 \\
\hline \multicolumn{3}{|c|}{ Causa da Indicação p/transplante de Córnea } \\
\hline Ceratocone & 02 & 66,66 \\
\hline Outra & 01 & 33,34 \\
\hline \multicolumn{3}{|c|}{ Causa da Indicação para transplante de rim } \\
\hline Esquistossomose & 01 & 25 \\
\hline Lúpus eritematoso sistêmico & 01 & 25 \\
\hline Infecção urinária & 01 & 25 \\
\hline Diabetes & 01 & 25 \\
\hline Total & 07 & 100 \\
\hline
\end{tabular}


$\mathrm{Na}$ abordagem, das pessoas que aguardavam pelo transplante, emergiram cinco categorias que traduziram seus sentimentos durante a espera: os sentimentos revelados no momento do diagnóstico: o início da espera; sentimentos que emergiram pelas mudanças na vida: novas necessidades e rotinas; os sentimentos desvelados durante o processo de enfrentamento; sentimentos que afastam ou aproximam o desejo pela realização do transplante e significando a espera pelo transplante.

\section{1- Os Sentimentos revelados no momento do diagnóstico: o início da espera}

Buscou-se identificar os sentimentos diante do diagnóstico da doença crônica, revelação da necessidade do transplante e realização de hemodiálise, desvelados nos relatos transcritos abaixo. Os nomes usados para as transcrições verbais são fictícios.

"Bem..., me deu tristeza. Tristeza por que eu sou um cara esclarecido e sabia que não era fácil. Sabia que não era uma coisa imediata, eu sabia que eu ia sofrer muito tempo né?" (Ônix).

Com essa fala, o paciente indica o sentimento que mais o incomoda, no caso, a tristeza pela doença. Da mesma forma, em todas prevaleceram sentimentos negativos tais como: sofrimento, revolta, tristeza, sentimentos de fragilidade e ansiedade, o sentimento positivo e a confiança apareceram em apenas uma das falas.

“..Eu procuro não pensar muito naquele dia que recebi a notícia que era renal crônica, entendeu, porque, pra mim, foi o pior dia da minha vida” (Pérola)

“..Eu, com quinze anos, nova, meu medo era mais de eu não conseguir o transplante e ficar cega." (Rubi).

"Fiquei assustada, por que uma notícia dessas né?..." (Esmeralda)

“..Você pensa que é uma coisa que vai passar. Depois de anos que a ficha caiu. Normal. No começo tudo é bom eu ainda passei quase dois anos urinando" (Diamante)

\section{2-Sentimentos que emergem pelas mudanças na vida: novas necessidades e rotinas.}

Ao explorar as mudanças na vida, surgiu mais uma unidade de sentido de importância peculiar condizente com as falas:

... A minha adolescência todinha foi mais dentro de casa, porque quando saia, a vista coisava logo, embaçava era tão ruim"(Rubi)

"A expectativa de vida é outra, e a saúde é a única riqueza que a gente tem. Nunca pensei em sustentar uma família com um salário..." (Diamante)

"Antes trabalhava, jogava, brincava fazia tudo. Quando eu entrei em tratamento, aí foi que a dificuldade aumentou, que eu deixei de jogar, que eu deixei de fazer muita coisa que hoje eu não faço mais..." (Diamante)

"...Perdi um pouco da vontade de estudar. Nunca fui de sair e agora não saio mesmo, tenho medo de passar mal na rua..." (Safira)
“....A partir do momento que você tá aqui, sente mal é como se fosse o fim, você pensa que você vai morrer..." (Diamante)

“...Principalmente eu, que nunca dependi de ninguém para fazer nada, precisava de alguém para dirigir pra mim, tinha alguém para me levar (para diálise), alguém para me pegar, termina que envolve as pessoas, a família de um modo geral...” (Pérola)

“... Eu perco quatro horas da minha vida em uma máquina, por esse motivo a rotina mudou (a fala se torna mais pausada)... Eu me adaptei porque foi necessário. (voz embargada e olhos lacrimejando)... eu não aceito... Eu aprendi a conviver porque eu sei que eu preciso da máquina para viver..." (Pérola)

"Eu não tenho uma vida melhor por causa desse problema... É muita dor de cabeça... muitas dores nos olhos." (Esmeralda)

"[... Uma coisa que eu aprendi é a ter paciência, a paciência foi o que eu tirei de lição de vida. Você tem que ter paciência para tudo, tudo tem seu tempo....]"(Ônix)

"A minha vida não mudou muito, eu dirijo, eu vou às festas, eu vou para casamento, aniversário, todo canto, procuro não ficar só em casa... Resolvo meus problemas, trabalho. Melhor do que ficar em casa aposentado, e isso eu não quero não. Viver só em casa assistindo televisão, presta não, aí eu vou morrer mais rápido." (Onix)

"Aí vou levando a minha vida, tem dia que você tá bem, tem dia que você tá ruim, tem dia que você tá com a autoestima, tem esperança de muita coisa, tem dia que você não quer nem falar com seu amigo. Só dentro de casa trancado, mais nada." (Diamante)

"Nunca fui de sair e agora não saio mesmo, tenho medo de passar mal na rua, sempre alguém precisa ir comigo porque de repente eu posso passar mal, e aí?" (Safira)

"Tenho uma vida normal com minha esposa e filhos, trabalho e ainda faço outra faculdade, estou cursando Direito. Nada mudou em relação a isso, acredito que seja pelo fato mesmo de eu não sentir tanta dificuldade e também pelo fato de ter acompanhamento médico sempre que preciso." (Ametista)

"A gente sempre muda, me tornei uma pessoa mais simples, mais calma que não pede muito da vida." (Safira)

Essas falas revelaram uma amplitude de sentimentos negativos relacionados às múltiplas mudanças ocorridas na vida, tais como: revolta, inutilidade, impotência, desconforto, perda, desilusão, vergonha, insatisfação e labilidade emocional, e ainda sentimentos positivos como: superação, amor e satisfação, direcionados aos vínculos familiares.

\section{3-Sentimentos desvelados durante o processo de enfrentamento}

À utilização de quatro recursos de enfrentamento, a saber: apoio familiar, religiosidade, trabalho e equipe de saúde, emergiram as seguintes falas. 
Givânya Bezerra de Melo, Anne Karolyne Barros Aguiar, Givanisy Bezerra de Melo, Vívian Marcella dos Santos Silva, Maria Cícera dos Santos de Albuquerque, Mércia Zeviani Brêda

Discursos dos sujeitos que evidenciaram o apoio familiar como recurso de enfrentamento:

"[... Se eu não tivesse a minha mãe? Aí eu passava necessidade, como eu passo às vezes... Eu luto mesmo, mas é por causa dos meus filhos, se não fossem eles, rapaz...]". (Diamante)

“...Meus pais são muitos preocupados, estão sempre comigo durante esse tempo todo... Sei que eles precisaram se dedicar muito a mim quando adoeci, e até hoje quando vou fazer hemodiálise a minha mãe vai comigo." (Safira)

A religiosidade, como recurso de enfrentamento, foi evidenciada nas seguintes falas dos sujeitos:

"Eu peço a Deus todos os dias que ele deixe eu vivo para eu criar os meus filhos, quando eles tiverem grandes". (Diamante)

"Eu tenho muita esperança. Eu não fico triste por que é uma coisa que Deus quer, e a gente tem que aceitar respeitar, tá nas mãos de Jesus né?” (Esmeralda)

"Eu peço a Deus que me dê muito tempo ainda para que a Medicina ainda progrida mais do que ela vem progredindo, pra vê se encontra uma solução pro meu caso. Mas, se eu tiver de ir hoje, eu tenho que ir mesmo, e eu tenho que aceitar, né?" (Ônix)

"Fiquei com medo de cegar, porque se não tiver um doador eu acho que é isso, eu penso. Mas aí eu tenho muita fé em Deus, Deus resolve! Eu não fico triste por que é uma coisa que Deus quer, e a gente tem que aceitar respeitar, tá nas mãos de Jesus, né?" (Esmeralda)

O trabalho, como recurso de enfrentamento, foi evidenciado nas falas:

"Quando eu fiquei renal crônica, eles me afastaram... expliquei que o que estava doente em mim era o rim, mas minha cabeça tá boa... então eu acho importante isso [...] por que eu imagino se eu não tivesse voltado a trabalhar, talvez não estivesse mais aqui, eu tenho certeza disso. E eu sou muito realizada naquilo que eu faço." (Pérola)

Por fim, as falas que evidenciam a equipe de saúde como recurso de enfrentamento:

"A assistência da equipe aqui é 100\%!... Eu tenho acompanhamento com o médico... A enfermagem é boa, sempre estão aqui. A psicóloga está sempre aqui... mas eu não gosto muito de conversa” (Diamante).

“...Só tenho consulta com o médico e às vezes com a nutricionista”... "Não tem psicólogo..." (Safira)

“...Eu só fui cadastrada e depois não tive mais nenhum acompanhamento..."(Esmeralda).

“... único tipo de assistência que estou recebendo é médica, pelo plano de saúde, sempre que preciso realizo exames e consultas.. Não. Nunca procurei atendimento psicológico, estou vivendo essa experiência tranquilamente, sou uma pessoa muito equilibrada.." (Ametista)
"Eu acho que é importante pra correlação de forças, para que você venha pressionar os órgãos, que devem funcionar e não estão funcionando..."

"A minha mãe realizou transplante de rins ano passado. É importante pra muita gente saber que não só ela está vivenciando essa experiência, de conhecer o problema dessa pessoa, é como se ao dividir essa experiência com alguém a situação torna-se um pouco mais leve, mais fácil. E também é uma forma de buscar soluções, de se informar." (Ametista)

E, mesmo aquelas falas que especificam o tipo de atendimento prestado ou, como é pensado que seja:

[...] - Tem uma psicóloga aí que sempre passa conversa com a gente. Ninguém aqui fala nada não sobre o transplante, ninguém fala nada! Conversa assim papo normal com a gente aqui, perguntando como é que a gente tá, se tem algum problema e tal, isso ela faz. Mas sobre transplante mesmo nada [...] (Ônix)

Nesse núcleo, foi possível captar sentimentos de motivação e segurança relacionados à família; confiança, fé, resignação e passividade, relacionados à religiosidade; superação e esperança relacionadas ao trabalho.

A equipe de saúde, como recurso de enfrentamento, despertou sentimentos positivos como amor, esperança e confiança, para a maioria dos entrevistados que aguardam transplante renal. Entretanto, para as pessoas que aguardam córnea, prevaleceram sentimentos negativos, pois após cadastrados na fila única de transplante, não receberam mais nenhum tipo de apoio ou informação.

\section{4-Sentimentos que afastam ou aproximam o desejo pela realização do transplante}

Nesse núcleo de sentido, captou-se uma multiplicidade de sentimentos que demonstraram ambivalência sobre o desejo da realização do transplante, como pode ser observado nos discursos a seguir:

"Eu não quero fazer transplante, porque, se a possibilidade de dá errado é grande e eu tiver que fazer de novo, pra mim ia ser sofrimento. Tenho medo também, já precisei ficar no hospital e não quero passar por outra cirurgia de novo. Eu não tenho interesse, para mim ficar doente de novo é melhor nem fazer."(Safira)

"Não sei se é bom fazer o transplante, se não é. Porque o transplante é só uma opção de vida, ele não vai ficar bom, é pra sair da máquina. Pelo menos é o que deu para entender desse tempo todinho que eu estou fazendo tratamento. Sair da máquina e continuar tomando remédio, não sei se é até pior."(Diamante)

"Sim, no início do ano fui chamado, mas não foi a Central de transplante que entrou em contato comigo e sim a minha médica que me disse que tinha surgido a oportunidade de realizar o transplante, mas como eu estava com viagem marcada não pude ir. Ela disse 
que eu voltaria para a fila e ficaria aguardando por uma nova oportunidade. Eu me senti tranquilo, pois foi uma questão de escolha. E como eu disse anteriormente a minha visão não está tão prejudicada, só sinto a diferença mesmo quando eu tiro o óculos. Comuniquei a minha decisão a ela e ela me informou que eu voltaria para a fila." (Ametista)

"Pra mim a espera é tranquila, pois eu não sinto tanta dificuldade, o óculos ainda dá um suporte bom." (Ametista)

"Eu tenho medo de cegar né mulher, é a pior coisa, depender dos outros, oi... (Emoção e choro). A pessoa tem a sua vista boa, depois ficar aí dependendo de um e de outra para tudo, a pessoa vai para todo canto e depois ficar sem, é difícil." (Esmeralda)

"Não, até agora nunca ligaram pra mim." (Esmeralda)

"Eu fiquei muito triste é claro, arrependido por não ter tomado certos cuidados antes, arrependido, com raiva de mim mesmo... um cara que descobriu a diabetes com pouca idade, eu tinha vinte e poucos anos, poderia ter me cuidado e não me cuidei. Aí, hoje eu sofro as consequências do fato de não ter cuidado mais da minha doença." (Ônix)

"Eu não quero fazer transplante. Eu tenho um primo que disse que se eu quisesse ele doava o rim, mas eu não quis, por que eu já soube de um caso de uma pessoa que doou o rim e depois precisou de transplante e não conseguiu, aí não dá. Eu sinceramente não tenho interesse nesse negócio de transplante." (Safira).

"Se aparecesse, a Central ligasse eu ia. Mas de mexer com alguém assim, eu sei que não acontece nada, eu não quero não. A minha mãe quer doar, a minha esposa, alguns primos. Não quero, não quero, já forçaram já tentaram colocar na minha cabeça. Você tem o seu é o seu, o meu estragou porque tinha que estragar mesmo. Sei que é muita ignorância, mas fazer o quê? é a vida." (Diamante)

A subjetividade dos sujeitos nessa unidade de sentido revelou sentimentos negativos, tais como: medo, relacionado aos sintomas físicos e a incerteza do sucesso do transplante, e ainda dúvida, insegurança, desesperança e compaixão pelo doador vivo. Apenas uma das pessoas revelou sentimentos positivos de tranquilidade e esperança.

\section{5- Sensibilizando a população para doação de órgãos: a luta pela vida}

O que foi expresso pelos sujeitos nesse núcleo de sentido revelou sentimentos de esperança, perseverança e amor pela vida, culminado como último apelo no decurso do estudo:

"Eu estou esperando um órgão, e quero viver mais um pouquinho, quero dizer para pessoas que querem ser doadoras, ou que caso venham a ter um parente acidentando (todo mundo está sujeito a isso), com morte encefálica, que naquele momento ele está salvando muitas vidas (voz embargada e choro). O órgão de alguém que já partiu pode salvar a vida de alguém." (Pérola).

"Eu acho bom a gente sempre conversar com a família, pra poder quando acontecer sempre doar. Porque assim, a gente quando está inscrita perde a esperança, aí você conseguir (pausa curta). Na minha opinião, pelo jeito que eu convivi, eu sempre vou levar isso como uma lição." ( Rubi)

"Rapaz, a melhor mensagem é quando você se coloca no lugar do outro, né? Se coloque no lugar do outro, veja o que o outro está passando, seja solidário, se você pode fazer por que você não faz? Vai lhe custar o quê? Tudo ali vai ser levado traça." (Ônix)

"Acho que a família podia ter mais consciência, porque morreu, é um ente querido, mas existe muita vida ali que pode salvar. Sete vidas!" (Diamante)

"Como eu disse, educação, conhecimento, informação é o que as pessoas precisam para se declarem como doadoras. Que elas procurem conhecer, saber como é importante a realização de transplante, o aumento no número de doações só ocorrerá quando esse for um assunto discutido, apresentado na escola, dialogado com as famílias." (Ametista)

"Que as famílias permitissem a doação de órgãos, ajudasse as pessoas que precisam, mas não ajudam. Eu acho assim, a pessoa que já morreu não volta mais para nada, então se tem um órgão para dar que dê, não vai servir mais pra nada. Deveria colocar mais gente para trabalhar, pra fazer as campanhas, pra pedir as pessoas, pra pedir ao pessoal que doasse né? Que doe as pessoas" (Esmeralda)

"Que é importante às pessoas saberem do assunto, tem muita gente fazendo hemodiálise e esperando por um órgão, quem puder doar que faça, é muito importante e pode salvar vidas" (Safira)

\section{DISCUSSÃO}

O diagnóstico de uma doença crônica e da necessidade do transplante é um momento que causa grande impacto para o paciente e seus familiares, desencadeando sentimentos múltiplos. A singularidade das reações depende da história de vida do paciente, dos vínculos constituídos, bem como da estrutura psíquica, evidenciando a influência das características pessoais do indivíduo diante da doença.

Dependendo da fase da vida em que a pessoa se encontra, a descoberta da necessidade do transplante e a espera para realizá-lo repercute de diversas maneiras em seu cotidiano. Como observado no estudo, quando descoberta na adolescência, há uma tendência de distanciamento de outros indivíduos da mesma faixa etária, acarretando em restrições do processo de socialização precedente do sentimento de diminuição de auto eficácia nas relações sociais. ${ }^{15}$

As repercussões na vida dos sujeitos na fase adulta denotaram 
forte sentimento de inutilidade, pois o papel social do adulto responsável, produtivo e autônomo não pode ser concretizado. A passividade e a dependência passaram a ser uma constante na vida desses indivíduos, levando-os a perdas econômicas significativas e sensação de impotência diante da vida, assemelhando-se a resultados de outros estudos. ${ }^{15}$

Quando a necessidade pelo transplante ocorre para uma pessoa idosa, é necessário considerar a existência do comprometimento do organismo decorrente do processo de envelhecimento; o corpo já não se apresenta como na fase anterior, pois com o quadro da doença presente, tornase mais evidente a disfunção do organismo. ${ }^{15}$

De maneira geral, as mudanças ocorridas na vida dos sujeitos desencadearam estresse físico e emocional. O tratamento por hemodiálise foi referido como um momento difícil, doloroso, de grande dor e sofrimento. Essa percepção corrobora com dados apresentados no estudo de Campos e Álvares, 16 que evidenciaram ainda ser esse tratamento suportado pela necessidade da manutenção da vida e pela esperança de realizar o transplante, o que gera ansiedade intensa, pois não há garantia da cura, apesar de todo sofrimento.

Nesse contexto, a ansiedade é definida como o medo de ser magoado ou de perder alguma coisa. ${ }^{16}$ Nos relatos dos sujeitos, esse sentimento relacionava-se ao medo de perder a visão, para os que aguardavam por córnea, e até mesmo a vida, para os que aguardavam por um rim.

A culpa pelo estado atual de saúde foi um sentimento manifestado por dois dos entrevistados, desencadeado quando o indivíduo passa a conter raiva dentro de si, adotando assim ações e pensamentos punitivos. ${ }^{16} \mathrm{O}$ estudo permitiu constatar que os indivíduos que manifestaram culpa pelo adoecimento estão mais pessimistas diante da possibilidade de receber o transplante e tendem ao isolamento social.

Para enfrentar as adversidades emergentes, os indivíduos utilizavam recursos de enfrentamento. Esses funcionam como mecanismos de ajustamento e suporte, que permitem a realização de negociações internas bem sucedidas entre seus desejos e a realidade não favorável. ${ }^{17}$

Estudos revelam que o apoio familiar é um dos principais recursos externos ao sujeito para o desenvolvimento de estratégias de enfrentamento. ${ }^{17} \mathrm{O}$ presente estudo também reforça tal afirmativa, ao trazer que a maioria dos sujeitos tem o apoio familiar como principal recurso para enfrentar as adversidades. Tal apoio transmite sentimento de segurança, confiança e amor, favorecendo assim o enfrentamento do problema.

A equipe de saúde foi identificada entre os recursos de enfrentamento usados pelos sujeitos, porém ela é quase inacessível. Os dados revelaram que alguns pacientes ao serem cadastrados na fila de transplante, não receberam informações e não sabiam sequer da inclusão na fila. Os que aguardam por córnea, ainda possuíam a situação agravada, se comparados aos que aguardavam por rim, pois os últimos frequentavam o centro de hemodiálise e recebiam, mesmo que de maneira consubstancial, algumas informações e apoio.

Esse déficit de informações e apoio resulta em consequências negativas para o paciente, deixando ainda mais árduo esse período na vida. Sabe-se que o conhecimento sobre a situação de saúde e as possibilidades terapêuticas favorecem a aquisição de controle da situação, e, consequentemente, contribuirão com a provisão de equilíbrio emocional e maior motivação para continuar cumprindo seu tratamento e aguardando pelo transplante..$^{18}$

Outro recurso de enfrentamento utilizado pelos sujeitos do estudo foi a religiosidade. É sabido que a dimensão religiosa tem significado importante na vida do ser humano, principalmente quando há iminência de doenças. No estudo, foi possível constatar que a dimensão religiosa é um recurso de enfrentamento utilizado por pessoas que aguardam por um órgão na fila única de transplante e a fé em Deus foi a principal estratégia identificada. A religiosidade também pode ser usada como parte da resolução do problema, sendo identificada como estratégia de enfrentamento baseada no problema.

Apesar das adversidades presentes na vida dessas pessoas, sentimentos positivos também permeiam o período de espera. Os vínculos familiares foram aproximados diante da necessidade do transplante, emergindo sentimentos como amor e respeito. Para outros, tal espera levou a mudanças de conceitos na vida, e a humildade, a simplicidade e o respeito atribuíram nova dimensão de ser e estar diante da vida.

Durante a espera pelo transplante, as pessoas enfrentam a situação, ora como salvação/vida, ora como grande risco/morte. Considera-se que toda situação de expectativa de receber um órgão constitui-se em uma vivência complexa e subjetiva por parte do paciente, deixando novos significados em sua história de vida. ${ }^{19}$

A ambivalência tão marcante nos discursos dos sujeitos pode favorecer ou afastar o desejo pela realização do transplante. O que emana do discurso deles são sentimentos dualistas relacionados ao doador vivo. Entre os pacientes que possuíam a possibilidade da doação entre vivos e doador falecido, todos esboçaram a preferência pela doação procedente de doador falecido, e a compaixão pelos possíveis doadores sobressaiu ao desejo de receber o órgão.

Dentre os sentimentos despertados, observou-se que a esperança também permeia esse período. Conforme afirmam Flores e Tomé, ${ }^{20}$ por vários momentos, o discurso dos sujeitos está associado à forma como o transplante poderia modificar suas vidas.

Apesar da trajetória de espera e dos infortúnios encontrados no caminho, percebe-se que todos compartilham o mesmo sentimento e buscam sensibilizar ou propor caminhos que tornem evidente a necessidade da doação de órgãos; um desses sentimentos é a esperança de um dia poder doar algum órgão, ou mesmo salvar a vida daqueles que também vivenciam os sentimentos de esperar por um órgão na fila única de transplante. 
Em relação ao desejo ou não por realizar os transplantes, as entrevistas constataram que esse desejo aparece dependendo da relação que a pessoa apresenta com o próprio corpo, do grau do comprometimento do órgão e como a doença lhe afeta. O tempo na fila única de transplante também apresenta forte influência na determinação dos sentimentos relatados, e a maior parte dos entrevistados referiu que, com o passar do tempo, as expectativas para a realização do transplante diminuem e a esperança e confiança também aparecem enfraquecidas.

Considerando a reflexão sobre a vivência da espera, podese afirmar que os discursos dos pacientes estão associados à forma como o transplante poderia modificar suas vidas e relacionam-no à vontade e maior certeza de viver.

Entre os momentos de angústia e incerteza, sobressaiu a capacidade do ser humano de tentar superar as adversidades e continuar lutando pela vida. Ficou evidenciado o apelo pela sensibilização da doação de órgãos; todos, até aqueles mais indiferentes em relação ao transplante, relatam que a doação é importante, consistindo assim, o próprio ato de salvar vidas.

\section{CONCLUSÃO}

A experiência da espera por um órgão é complexa; a incerteza, o medo e a dualidade vida/morte tornam-se uma constante para as pessoas envolvidas no processo. Na maioria das vezes, essa é uma espera silenciosa, que pode tornar-se solitária com o passar do tempo. Conhecer e compartilhar os sentimentos revelados por essas pessoas é refletir sobre a realidade de centenas de seres humanos que, pela necessidade do transplante, têm o curso da sua existência suspenso, principalmente quando aguardam um órgão vital.

Esses sentimentos devem ser respeitados e acolhidos por toda sociedade e, principalmente, pelos profissionais de saúde. A subjetividade deve ser valorizada durante a assistência em todas as fases do transplante. O pragmatismo das ações diárias acaba mascarando essa fase, evidenciando assim a necessidade de investir mais em educação permanente.

O enfermeiro tem um papel primordial em todas as fases do transplante; entretanto, há a necessidade da realização de estudos científicos mais aprofundados, e ainda da incorporação de técnicas assistenciais relacionais na prática desse profissional, que perpassem a dimensão físico-biológica, capacitando-lhes para prestar uma assistência qualificada, de acordo com as peculiaridades de cada pessoa.

O estudo teve a proposta de despertar nova percepção sobre o período de espera pelo transplante. Ressalte-se a importância de que mais estudos sejam realizados no cenário brasileiro, buscando a associação da subjetividade dessas pessoas à prática assistencial.

A academia deve valorizar a formação dos profissionais de saúde, a discussão sobre transplantes de órgãos, bem como a aquisição de habilidades de cuidado direcionadas a esse público. Destaca-se ainda a importância e a necessidade de investimentos em campanhas educativas mais eficazes que possam contribuir para o aumento do número de órgãos disponíveis.

\section{ABSTRACT}

Purpose: To identify the feelings of people who are waiting for an organ or tissue in a single transplantation list. Methods: This is a descriptive qualitative research conducted among seven people waiting for a transplant. Data were subjected to content analysis in the form of thematic or categorical analysis. Results: characterization of the subjects, $57 \%$ were female, ages between 22 and 62 years mean waiting for cornea, kidney and 2.1 years, 3.8 years. Five units of sense were identified in the beginning of the waiting: prevalence of negative feelings like sadness and uncertainty following the diagnosis and the need for transplantation; changes in life arouse negative feelings of worthlessness, guilt and passivity related to changes in the financial, leisure, freedom, life expectancy status, as well as positive feelings such as hope and overcoming by the appreciation for the family and life; in the confrontation, the family was the resource increasingly searched by the subjects, emerging positive feelings of trust and security; healthcare was taken along the waiting period by positive feelings to those waiting for a kidney and negative for those awaiting for a cornea by not attaing it; in such ambivalence it was disclosed positive feelings bringing the desire for the transplant, and causing negative feelings that keep life motivated by the death/life duality, compassion for the living donor; in the call for life , positive feelings of hope were disclosed before the awareness messages to encourage organ donation. Conclusion: Regardless the body, the wait for a transplant is a stressful time in the life of an individual, triggering multiple feelings which need to be assessed. Results address to foster the discussion on nursing education and practice about the importance of valuing the subjectivity of people waiting for a transplant, the need for health education during the waiting period, as well as improving the Organ and Tissue Harvesting System.

Keywords: Nursing; Feelings; Organ Transplantation; Waiting Lists. 


\section{REFERÊNCIAS:}

1. Soares CO. O transplante e a questão da alteridade: biologia e subjetividade [tese de dissertação]. Rio de Janeiro: Escola Nacional de Saúde Pública Sergio Arouca, 2009.

2. BRASIL. Portal de Transplantes [homepage na Internet]. Transplantes Realizados em 2011. Acesso em: fev 2012. Disponível em: < http://aplicacao.saude.gov.br/ saude/ transplante/\%C3\%81rea_Especializada/relatorios_estatisticos/ transplantes-realizados $>$.

3. Garcia GG, Harden PN; Chapman JR. The global role of kidney transplantation. Kidney Int. 2012;81:425-7.

4. Brasil. Decreto No 2268, de 30 de junho de 1997. Diário Oficial da União. Brasília, Distrito Federal (Jul 30, 1997).

5. Brasil. Portaria GM nº 3.407 de 05 de agosto de 1998. Diário Oficial da União. Brasília, Distrito Federal (06 Ago, 1998).

6. Associação Brasileira de Transplante de Órgãos - ABTO. Acesso em [12 de Dez 2012]. Disponível em: www.abto.gov.br.

7. Brasil. Lei no 9.434 de 04 de fevereiro de 1997. Diário Oficial da União. Brasília, Distrito Federal (04 Fev, 1997).

8. Bérte R. Doação e transplante de órgãos e tecidos: informação de acadêmicos [tese]. Santa Catarina: Universidade do ContestadoUnC; 2003.

9. Roza BA; Thomé T; Neto BHF; Schirmer J. Doação de órgãos no Brasil: podemos evoluir? Rev Mundo Saúde. 2009;33(1):43-8.

10. Marinho A. A situação dos transplantes de órgãos no Brasil. Instituto de Pesquisa econômica Aplicada. Brasília. Fev 2009.
11. Li PK; Chu Kh Chow KM; Lau MF; Leung CB; Kwan BC et al. Cross sectional survey on the concerns and anxiety of patients waiting for organ transplants, Nephrology. 2012:17:514-8.

12. Viscott D. A linguagem dos sentimentos. $17^{\mathrm{a}}$ Ed. Summus: São Paulo, 1982.

13. Minayo MCS. O desafio do conhecimento, pesquisa qualitativa em saúde. $5^{\mathrm{a}}$ ed. Hucitec: São Paulo,1996.

14. Oliveira MM. Como fazer pesquisa qualitativa. $3^{\text {a }}$ ed. Vozes: São Paulo, 2007.

15. Cuker GM, Fragani ECSF. As dimensões psicológicas da doença renal crônica [dissertação]. Santa Catarina: Faculdade de Psicologia, Universidade do Extremo Sul Catarinense (UNESC), 2009.

16. Campos EMP, Bach C; Alvares M. Estados emocionais do paciente candidato a transplante de medula óssea. Psicol Teor Prat. Dez. 2003;5(2):23-6.

17. Costa P, Leite RCBO. Estratégias de enfrentamento utilizadas pelos pacientes oncológicos submetidos a cirurgias mutiladoras. Rev Bras de Canc. 2009;55(4):355-64.

18. Rossiter M, Valença MP, VALOIS AA. Trasplante renal: conhecimento do paciente acerca do período perioperatório. J Bras Transpl. 2012;15 (1):162050.

19. Waschburger EMP; Ribas RF; Ferreira MAW, Macedo MMK. Candidatos a transplante de pulmão: configurações traumáticas da vivência de espera pela vida. IV Mostra de pesquisa da PósGraduação PUCRS;11 a 14 Ago 2008; Rio Grande do Sul, 2008.

20. Flores RV, Thomé EG. Percepções do paciente em lista de espera para transplante renal. Rev Bras Enferm. 2004;57(6):687-90. 